\title{
Family planning clients at a Tertiary hospital in Niger Delta, Nigeria: Where they on any contraceptive method prior to first visit?
}

\author{
Nonye-Enyidah Esther I ${ }^{1,}{ }^{*}$, Enyidah Nonyenim $S^{2}$ and Jumbo $A^{1}$ \\ ${ }_{1}^{1}$ Department of Obstetrics and Gynaecology, Rivers State University Teaching Hospital, Port Harcourt, Nigeria. \\ ${ }^{2}$ Department of Medicine, Rivers State University Teaching Hospital, Port Harcourt, Nigeria.
}

Magna Scientia Advanced Research and Reviews, 2021, 01(03), 022-029

Publication history: Received on 17 January 2021; revised on 20 February 2021; accepted on 22 February 2021

Article DOI: https://doi.org/10.30574/msarr.2021.1.3.0018

\begin{abstract}
Background: Maternal and child morbidity and mortality in developing countries have been shown to be reduced by effective use of contraceptive methods. Contraceptive use also improves the lives of women and children. Experience with previous use of contraceptives may affect the uptake rate of modern contraceptive methods.

Aim and objective: To determine the pattern of previous contraceptive usage, uptake rates of the contraceptives, the continuation and discontinuation rates and the sources of prior contraceptives. The socio-demographic characteristics and sources of information on current contraceptive use at the Rivers State University Teaching Hospital during the study period.

Methods: This was a retrospective study of clients' records in family planning clinic at theRivers State University Teaching (RSUTH) over a period of five years. Their cards were retrieved, reviewed; data was extracted, coded and analyzed using the statistical package for social sciences (SPSS) IBM version25.0 (Armonk, NY).

Results: There were 874 contraceptive acceptors attending family planning clinic between $1^{\text {st }}$ January, 2015 and $31^{\text {st }}$ December, 2019 in the centre. Of this number, 566 (64.8\%) were using one form of contraceptive method or the other while $308(35.2 \%)$ were not on any form of contraception. Of this 566 women who used contraceptive method prior to their visit to the family planning clinic, intrauterine contraceptive device (IUCD) use accounted for 118 (20.8\%), others were barrier method, 107 (18.9\%), oral contraceptive pills (OCPs), 95 (16.8\%), depot medroxyprogesterone acetate (DMPA), 72 (12.7\%), implanon, 40 (7.1\%), noristerat, 36 (6.4\%), postinor, 28 (5.0\%), withdrawal method, $26(4.6 \%)$ and calendar method, 24 (4.2\%). Most of the previous contraceptives used came from Government hospital accounting for $44.4 \%$. Most women (72\%) obtained their information concerning current contraception from clinical personnel. More than half of the clients (64.1\%) were within the age range of 30-39 years and $2(0.2 \%)$ were below 20 years. Age range for the study was 19-51years. Majority of the clients (70.7\%) were multipara while $162(18.5 \%)$ were grandmultipara. Modal parity was para 3. The women with formal education were 867 (99.2\%). Married women and Christians accounted for843 (96.5\%) and 867 (99.2\%) respectively.
\end{abstract}

Conclusion: Most clients were in their thirties, married, educated and multiparous. Thirty five percent of the women were not using any form of contraceptive method which is quite alarming and definitely would have led to unwanted pregnancies and possibly induced abortions with its sequalae.

Keywords: Acceptors; Nigeria; Previous contraception; RSUTH

${ }^{*}$ Corresponding author: Nonye-Enyidah Esther I

Department of Obstetrics and Gynaecology, Rivers State University Teaching Hospital, Port Harcourt. 


\section{Introduction}

Observing trends and patterns of contraceptive use, nonuse, socio-demographic characteristics of clients and method type in the population aids in understanding the rate of unintended pregnancy [1,2]. Effective contraception has been proven to reduce maternal morbidity and mortality [3-5]. In Nigeria, maternal mortality ratio is 576 deaths per 100,000 live births which is high. Also Nigeria Democratic Health survey (NDHS) data showed that only $14.5 \%$ of couples in Nigeria use various methods of contraception [6]. The clients with prior contraceptive use are more likely to be more aware of the various contraceptive methods including their side effects [5, 7]. Also non-satisfaction with a previous contraceptive influences future choices and may even cause outright non use or changing to another more or less effective methods to prevent pregnancy [8-10].

There are a lot of local and international studies on contraceptives but scanty reports are documented on prior contraceptive use. This study is important to document the pattern of prior contraceptive use among family planning clients at the RSUTH and this will go a long way in counseling the clients to improve on the use of contraceptives. It will also assist in research and training of service providers.

\section{Material and methods}

This is a retrospective study carried out at the family planning clinic of the Rivers State University Teaching Hospital (RSUTH) in Port Harcourt, the capital of Rivers State in Niger Delta, Nigeria. The state has a population of more than 5 million people with different tribes and languages. The clinic gets its clients primarily from the postnatal, gynaecological and outpatient clinics. Clients from outside the State also attend the clinic. The family planning clinic has its own records section different from the hospital records and this makes it easy to retrieve the clients' case notes. The clinic runs from 8 a.m to 4p.m on Mondays to Fridays.

The clients were warmly welcomed at presentation by trained family planning nurses and physicians who also counseled them. The clients were allowed to make informed choice based on their needs and available contraceptives suitable for them. Thereafter medical history and clinical examination were done. Urine analysis and pregnancy test were also done for the clients before the chosen contraceptives were administered to them.

The record cards of all the clients that accepted the available contraceptives between $1^{\text {st }}$ January, 2015 and $31^{\text {st }}$ December, 2019 were retrieved and studied. The information extracted from the cards included the socio-demographic characteristics of the clients, source of information concerning contraception, previous contraceptives used by the clients, source of previous contraceptives and the current contraceptives in use. The data was analyzed with the statistical package for social sciences (SPSS) IBM version 25.0 (Armonk, NY) using frequency counts and percentages.

\section{Results and discussion}

There were 874 contraceptive acceptors during the study period, out of which 566 (64.8\%) previously used contraceptive methods prior to first visit to the family planning clinic and $308(35.2 \%)$ did not use any method of contraception. Of the 566 who previously used contraception, 118 (20.8\%), 107 (18.9\%), 95 (16.8\%), 72 (12.7\%), 40 (7.1\%), $36(6.4 \%), 28(5.0 \%), 26(4.6 \%)$ and $24(4.2 \%)$ were for IUCD, barrier method, OCPs, DMPA, implanon, noristerat, postinor, withdrawal and calendar methods respectively. This is shown in figure 1.

The ages of the clients ranged from 19 to 51 years. Majority of the clients, 560 (64.1\%) were between the age range of 30 to 39 years. Two $(0.2 \%)$ teenagers who did not use any method of contraception prior to the first visit were single. Three $(0.3 \%)$ women were age 50 years and above. The mean age for the study was $33.7 \pm 5.5$ years. Majority of the clients were multiparous women, $618(70.7 \%)$ and Christians $867(99.2 \%)$. The parity range was 0 to 10 and modal parity was para 3 . Twenty three $(2.6 \%)$ women were nullipara while $162(18.5 \%)$ were grandmultipara. Eight hundred and sixty seven (98.2\%) of the clients had formal education out of which $483(55.3 \%)$ had secondary level of education while $352(40.2 \%)$ and $32(3.7 \%)$ had tertiary and primary levels of education respectively. Most of the clients, were married (96.5\%) while $31(3.5 \%)$ were single. The socio-demographic characteristics of the contraceptive acceptors are shown in table 1. 


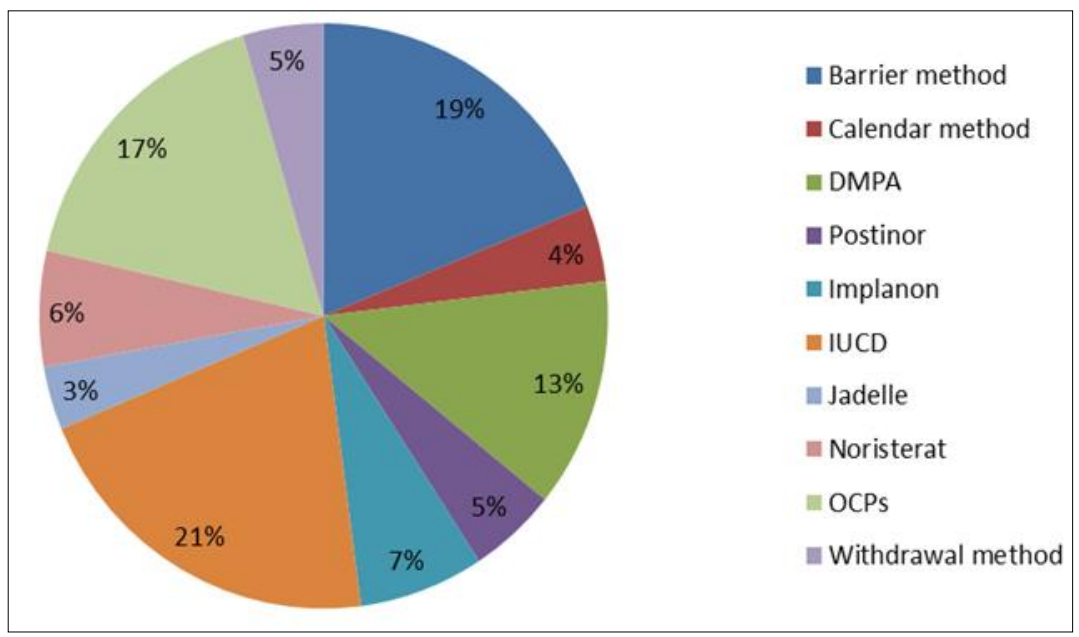

Figure 1 Previous contraceptive methods used by the clients.

Table 1 Socio-demographic characteristics of the clients.

\begin{tabular}{|l|l|c|}
\hline Variable & No. & $\begin{array}{l}\text { Percentage } \\
\text { (\%) }\end{array}$ \\
\hline AGE & & \\
\hline$<20$ & 2 & 0.2 \\
$20-24$ & 39 & 4.5 \\
$25-29$ & 137 & 15.7 \\
$30-34$ & 325 & 37.2 \\
$35-39$ & 235 & 26.9 \\
$40-44$ & 109 & 12.5 \\
$45-49$ & 24 & 2.7 \\
$\geq 50$ & 3 & 0.3 \\
\hline Educational status & & \\
\hline No formal education & 7 & 0.8 \\
Primary & 32 & 3.7 \\
Secondary & 483 & 55.3 \\
Tertiary & 352 & 40.2 \\
\hline Religion & & \\
\hline Christianity & 867 & 99.2 \\
Islam & 7 & 0.8 \\
\hline Parity & & \\
\hline Nullipara & 23 & 2.6 \\
Primipara & 71 & 8.1 \\
Multipara & 618 & 70.7 \\
Grand multipara & 162 & 18.5 \\
\hline Marital status & & \\
\hline Single & 31 & 3.5 \\
married & 843 & 96.5 \\
\hline
\end{tabular}


Sources of information for all the contraceptive methods are shown in table 2. Six hundred and twenty nine (72\%) women obtained their information concerning contraception from clinical personnel, 131 (15\%) from friends and relatives, 43 (4.9\%) from community health workers and 34 (3.9\%) from print and media. Others are radio/television, $20(2.3 \%)$ and outreach, $17(1.9 \%)$. The sources of previous contraceptives used were Government hospitals, 388 (44.4\%) and private hospitals, 128 (14.6\%). Over 350 (41\%) clients did not obtain any method of contraception from any source. This includes 308 clients with no method of contraception, 26 clients using withdrawal method and 24 clients with calendar method. This is shown in figure 2.

Table 2 Sources of information on contraception

\begin{tabular}{|l|l|l|}
\hline Sources of Information & No. of clients & Percentage (\%) \\
\hline Clinical personnel & 629 & 72 \\
\hline Friends/relatives & 131 & 15 \\
\hline Community Health Worker & 43 & 4.9 \\
\hline Print Media & 34 & 3.9 \\
\hline Radio/Television & 20 & 2.3 \\
\hline Outreach & 17 & 1.9 \\
\hline
\end{tabular}

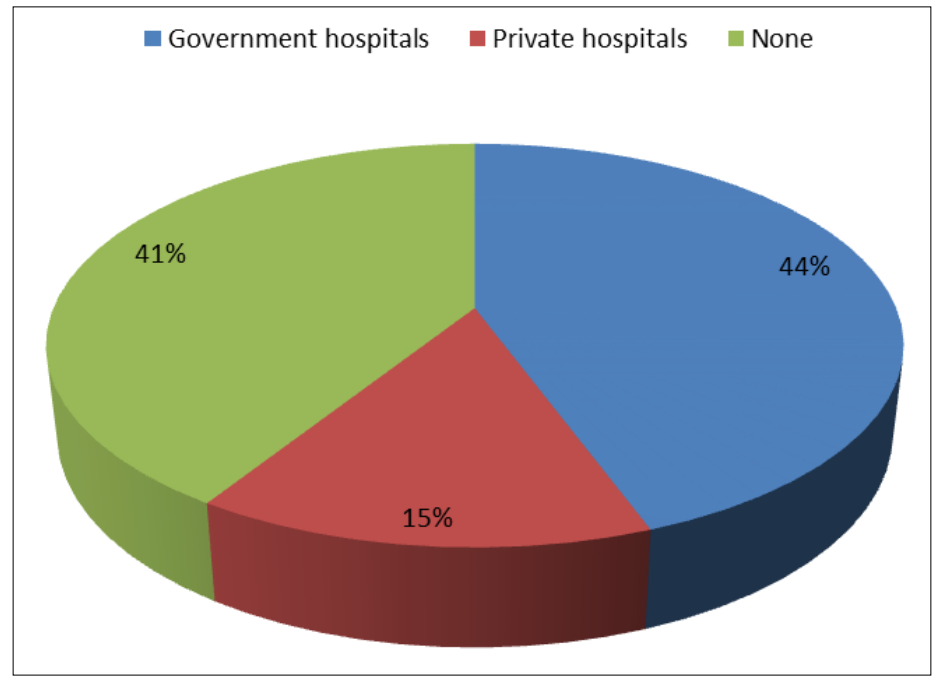

Figure 2 Sources of previous contraceptives used by the clients.

Out of 24 women who previously used calendar method, 8 (33.3\%) changed to implanon, 6 (25\%) to IUCD, 4 (16.7\%) to jadelle, $3(12.5 \%)$ to DMPA, $2(8.3 \%)$ to norethisteroneoenanthate (noristerat) and 1 (4.2\%) to OCPs. Eight women each $(30.8 \%)$ who were currently on IUCD and implanon respectively had used withdrawal method. Other women who previously used withdrawal method include $6(23 \%)$ that changed to jadelle, and $2(7.7 \%)$ each that changed to condom use and DMPA respectively. Of 60 clients that previously used implant, $39(65 \%)$ continued to use implanon and 8 $(13.3 \%)$ continue with jadelle making the continuation rate to be $78.3 \%$. Seven $(11.7 \%)$ changed to mirena and $6(10 \%)$ changed to IUCD. Out of 108 women that used injectable, $51(47.2 \%)$ and $20(18.5 \%)$ continue with DMPA and noristerat respectively giving a continuation rate of $65.7 \%$. The rest who changed to other forms of contraception were $17(15.7 \%)$ women to implanon, $8(7.4 \%)$ to jadelle, $7(11.7 \%)$ to IUCD, $4(3.7 \%)$ to OCPs and $1(1 \%)$ to mirena. Of the 28 clients that used emergency contraception (postinor), more than half $(57.1 \%)$ changed to implanon, 5 (18\%) to jadelle, 3 $(10.7 \%)$ to DMPA and $2(7.1 \%)$ each to IUCD and OCPs respectively.

Eighty one (68.6\%) and 9 (7.6\%) women who currently used IUCD ( $\mathrm{Cu}$ T) and mirena respectively had used IUD previously giving a continuation rate of $76.2 \%$. Sixteen (13.6\%) changed to implanon, $9(7.6 \%)$ to jadelle, $2(1.7 \%)$ and $1(0.9 \%)$ to DMPA. Of the 95 clients who used OCPs, $29(30.5 \%)$ continued with it while $25(26.3 \%)$ changed to implanon, $15(15.8 \%)$ to jadelle, $14(14.8 \%)$ to IUCD, $10(10.5 \%)$ to DMPA and $2(2.1 \%)$ to noristerat. Thirty seven (34.6\%), 19 
(17.8\%), 18 (16.8\%), 13 (12.1\%), 12 (11.2\%), 5 (4.7\%) and 3 (2.8\%) women who currently used implanon, jadelle, IUCD, DMPA, barrier method (condom), noristerat and OCPs respectively had a prior condom use. Lastly, out of 308 women who did not use any method of contraception prior to their first visit, chose and used the following: 117 (38\%) implanon, 79 (25.6\%) IUCD, 68 (22.2\%) jadelle, 18 (5.8\%) DMPA, 12 (3.9\%) OCPs, 8 (2.6\%) noristerat and 6 (1.9\%) started using condoms. These are shown in table 3.

Table 3 Pattern of change from previous contraceptive method to current contraceptives.

\begin{tabular}{|c|c|c|c|c|c|c|c|c|c|c|}
\hline $\begin{array}{l}\text { Previous } \\
\text { contraceptives }\end{array}$ & $\begin{array}{l}\text { Condom } \\
\text { No (\%) }\end{array}$ & $\begin{array}{l}\text { IUCD } \\
\text { No (\%) }\end{array}$ & $\begin{array}{l}\text { Mirena } \\
\text { No (\%) }\end{array}$ & $\begin{array}{l}\text { OCPs } \\
\text { No } \\
(\%)\end{array}$ & $\begin{array}{l}\text { Noristerat } \\
\text { No (\%) }\end{array}$ & $\begin{array}{l}\text { DMPA } \\
\text { No } \\
\text { (\%) }\end{array}$ & $\begin{array}{l}\text { Jadelle } \\
\text { No (\%) }\end{array}$ & $\begin{array}{l}\text { Implanon } \\
\text { No (\%) }\end{array}$ & $\begin{array}{l}\text { Total } \\
\text { No }\end{array}$ & $\%$ \\
\hline Calendar & - & $\begin{array}{c}6 \\
(25)\end{array}$ & - & $\begin{array}{c}1 \\
(4.2)\end{array}$ & $\begin{array}{c}2 \\
(8.3)\end{array}$ & $\begin{array}{c}3 \\
(12.5)\end{array}$ & $\begin{array}{c}4 \\
(16.7)\end{array}$ & $\begin{array}{c}8 \\
(33.3)\end{array}$ & 24 & 2.7 \\
\hline Withdrawal & $\begin{array}{c}2 \\
(7.7)\end{array}$ & $8(30.8)$ & - & - & - & $2(7.7)$ & $\begin{array}{c}6 \\
(23.0)\end{array}$ & $\begin{array}{c}8 \\
(30.8)\end{array}$ & 26 & 3.0 \\
\hline Implant & - & $6(10.0)$ & $7(11.7)$ & - & - & - & $\begin{array}{c}8 \\
(13.3)\end{array}$ & $\begin{array}{c}39 \\
(65.0)\end{array}$ & 60 & 6.9 \\
\hline Injectable & - & $\begin{array}{c}7 \\
(6.5)\end{array}$ & $\begin{array}{c}1 \\
(1.0)\end{array}$ & $\begin{array}{c}4 \\
(3.7)\end{array}$ & $\begin{array}{c}20 \\
(18.5)\end{array}$ & $\begin{array}{c}51 \\
(47.2)\end{array}$ & $\begin{array}{c}8 \\
(7.4)\end{array}$ & $\begin{array}{c}17 \\
(15.7)\end{array}$ & 108 & 12.4 \\
\hline Postinor & - & $\begin{array}{c}2 \\
(7.1)\end{array}$ & - & $\begin{array}{c}2 \\
(7.1)\end{array}$ & - & $\begin{array}{c}3 \\
(10.7)\end{array}$ & $\begin{array}{c}5 \\
(18.0)\end{array}$ & $\begin{array}{c}16 \\
(57.1)\end{array}$ & 28 & 3.2 \\
\hline IUCD & - & $\begin{array}{c}81 \\
(68.6)\end{array}$ & $\begin{array}{c}9 \\
(7.6) \\
\end{array}$ & $\begin{array}{c}2 \\
(1.7) \\
\end{array}$ & - & $\begin{array}{c}1 \\
(0.9) \\
\end{array}$ & $\begin{array}{c}9 \\
(7.6) \\
\end{array}$ & $\begin{array}{c}16 \\
(13.6) \\
\end{array}$ & 118 & 13.5 \\
\hline OCPs & - & $\begin{array}{c}14 \\
(14.8)\end{array}$ & - & $\begin{array}{c}29 \\
(30.5)\end{array}$ & $\begin{array}{c}2 \\
(2.1)\end{array}$ & $\begin{array}{c}10 \\
(10.5)\end{array}$ & $\begin{array}{c}15 \\
(15.8)\end{array}$ & $\begin{array}{c}25 \\
(26.3)\end{array}$ & 95 & 10.9 \\
\hline Barrier/condom & $\begin{array}{c}12 \\
(11.2)\end{array}$ & $\begin{array}{c}18 \\
(16.8\end{array}$ & - & $\begin{array}{c}3 \\
(2.8)\end{array}$ & $\begin{array}{c}5 \\
(4.7)\end{array}$ & $\begin{array}{c}13 \\
(12.1)\end{array}$ & $\begin{array}{c}19 \\
(17.8)\end{array}$ & $\begin{array}{c}37 \\
(34.6)\end{array}$ & 107 & 12.2 \\
\hline No method & $\begin{array}{c}6 \\
(1.9)\end{array}$ & $\begin{array}{c}79 \\
(25.6)\end{array}$ & - & $\begin{array}{c}12 \\
(3.9)\end{array}$ & $\begin{array}{c}8 \\
(2.6)\end{array}$ & $\begin{array}{c}18 \\
(5.8)\end{array}$ & $\begin{array}{c}68 \\
(22.2)\end{array}$ & $\begin{array}{c}117 \\
(38.0)\end{array}$ & 308 & 35.2 \\
\hline
\end{tabular}

\section{Discussion}

Research has shown that women use and discontinue contraceptive methods based on the characteristics of the method, side effects, ease of use and its effectiveness [11]. Method use is also affected by access to and quality of family planning services [12]. In a study done by Mohammed DA et al in the northern part of Nigeria, the commonest type of prior contraception was injectable accounting for $45.2 \%$ and current contraception was IUCD [5]. In our study, the reverse is the case as the commonest previous contraception was IUCD accounting for $20.8 \%$ similar to a study done in Jos [12] while the commonest current contraception was implanon accounting for $32.4 \%$ of all the contraceptive use. This is not surprising as our women are changing more to modern forms of contraceptives. In our study, $64.8 \%$ of the clients had used prior contraception unlike $43.8 \%$ and $55.6 \%$ seen in similar studies $[5,14]$.

Most of the women were between 30-39 tears, multiparous and had formal education like in other studies [5,10,15]. It has been shown that the more educated a woman is, the more likely she is to use modern contraceptive methods [16]. Educated women appreciate the importance of family planning in order to reduce the number of children they have and give them quality care and education [16]. Multiparous women formed the highest group that used previous contraceptives and nulliparas were the least. This is similar to other studies $[5,15,17,18]$. Most women who used prior contraceptives were Christians. This is not surprising because majority of the population in southern Nigeria are Christians and this finding is in keeping with other similar studies done in southern Nigeria $[17,18]$ but not in keeping with a similar study done in the northern part of Nigeria where Moslems are dorminant $[5,19]$.

The least age group was less than 20 years. This is in keeping with the studies done in Ilorin, Port-Harcourt and Kaduna $[5,14,17,18]$. Only two single teenagers $(0.2 \%)$ used contraceptives throughout the study period. The low usage among the adolescents is an issue of concern in Nigeria where more than $60 \%$ of teenagers are sexually active, accounting for 
$60 \%$ of 600,000 induced abortions in Nigeria $[18,20]$. These teenagers especially single ones who might be shying away from getting the contraceptives from the family planning clinics resort to buying them from the pharmacy and drug shops. It could also be due to abstinence from sex which is preached at this age or they may be afraid of the side effects of the drugs. The uptake of contraceptives by teenagers could also be affected by the discouraging attitudes of health care givers towards them $[18,20]$. Therefore family planning clinics should be youth friendly and encourage teenagers and young unmarried women to visit the clinic for contraception.

Most of the women (72\%) knew about family planning from clinic personnel. This is similar to what obtains in most parts of Nigeria and indeed Sub-Sahara Africa [18,20-22] but in contrast to the study done in south western Nigeria where print and media played a very important role in the dissemination of information concerning contraception [23].

The attitude of health providers towards a particular contraceptive method in developing countries has been shown to influence continuation rates among clients through the kind of information they give when interacting with clients [2426]. Therefore there is the need to evaluate the interaction between the contraceptive providers and the clients.

Radio, television, print and media contributed to $6.2 \%$ of sources of information in this study. This is poor; therefore to have an increase in the uptake rate of contraceptives, the source of information should go beyond the clinical personnel and involve everybody including government and non-governmental organizations.

Three hundred and eight (35.2\%) clients did not use any form of contraceptive method. This is very risky because they were highly exposed to having unintended pregnancy. It is a good development now that all of them had started using one form of contraception or the other. Low levels of education, women's and partner's disapproval of modern contraceptives, religions, beliefs, misconceptions, fear of side effects of modern contraception, use of unproven methods and infrequent sex are some of the reasons for non-use of contraception in sub-Sahara Africa $[27,28]$.

None of the clients who were using calendar and withdrawal methods continued with the methods. They all went for more effective and modern methods of contraception especially sub-dermal implants and intrauterine devices. Most of the clients who used other methods of contraception like the IUCD, injectables and implants preferred to continue with them. This finding is similar to a study done in Kaduna, Northern Nigeria [5].This shows how effective these contraceptives are and that the women were able to tolerate the drugs.

\section{Conclusion}

Most clients were young, married, educated and multiparous. Intrauterine contraceptive device (IUCD) was the commonest prior contraceptive used by the clients while calendar and withdrawal methods were the least previous methods used. Most information on prior contraceptives came from clinical personnel with a poor contribution from the print and media. Thirty five percent of the women were not using any form of contraception which would have led to unwanted pregnancies. Lastly, most clients preferred to continue with the prior modern method of contraception.

\section{Compliance with ethical standards}

\section{Acknowledgments}

We wish to express our profound gratitude to the staff of the family planning clinic for their tremendous assistance rendered for this study.

\section{Disclosure of conflict of interest}

Authors have declared that no competing interests exist.

\section{Statement of ethical approval}

Ethical approval was given by the hospital's ethics committee.

\section{References}

[1] Kavanaugh ML, Jerman J. Contraceptive method use in the United States: trends and characteristics between 2008, 2012 and 2014. Contraception. 2018; 97:14-21. 
[2] Finer LB, Zolna MR. Declines in unintended pregnancy in the United States, 2008-2011. Med. 2016; 374: 843-52.

[3] Kana MA, Tagurum YO, Hassan ZI, Afolanranmi TO, Ogbeyi GO, Difa JA, Amede P and Chirdan O0. Prevalence and determinants of contraceptive use in rural Northeastern Nigeria: Results of a mixed qualitative and quantitative assessment. Annals Nigerian Medicine. 2016; 10:3-10.

[4] Ahmed S, Li Q, Liu L,Tsui AO. Maternal deaths averted by contraceptive use: an analysis of 172 countries. Lancet. 2012; 380:111- 25.

[5] Mohammed DA, Adze J, Bature S, Abubakar A, Mohammed C, Taingson M, Airede L. Pattern of contraception among prior female users in a tertiary hospital in Northern Nigeria. Research Journal of women's health. $2017 ; 4$ (4): 1-7.

[6] National Population Commission [Nigeria] and ICF International. Nigeria Demographic and Health Survey 2013. Abuja, Nigeria, Rockville, Maryland, USA. 2014.

[7] Sucato GS, Bhatt SK, Murray PJ, Ott MA. Transdermal contraception as a model for adolescent use of new methods. J Adolesc Health. 2011; 49:357-62.

[8] He K, Dalton VK, Zochowski MK, Hall KS. Women's Contraceptive Preference-Use Mismatch. J Womens Health (Larchmt). 2017; 26:692- 701.

[9] Moreau C, Cleland K,Trussell J. Contraceptive discontinuation attributed to method dissatisfaction in the United States. Contraception. 2007; 76:267-72.

[10] Kopp DM, Rosenberg NE, Stuart GS, Miller WC, et al. Patterns of contraceptive adoption, continuation and switching after delivery among Malawian women. PLOS one Journal. 2017; 12 (1): e0170284: 1-12.

[11] Daniels K, Mosher WD, Jones J. Contraceptive methods women have ever used: United States. 1982-2010. Vital Health Stat. 2013; 62: 1-15.

[12] Grady CD, Dehlendorf C, Cohen ED, Schwarz EB, Borrero S. Racial and ethnic differences in contraceptive use among women who desire no future children, 2006-2010 National Survey of Family Growth. Contraception. 2015; 92: 62-70.

[13] Mutihir JT, Pam VC. Overview of contraceptive use in Jos University Teaching Hospital, north central Nigeria. Niger J ClinPract. 2008; 11:139-43.

[14] Ajiboye A, Adesina KT, Abdul IF, Ezeoke GG. Patterns of contraceptive usage at family planning clinics in Ilorin, Nigeria. Bangladesh Medical Journal. 2015; 44(3): 140-145.

[15] Ajai AI, Adeniyi OV, Akpan W. Use of traditional and modern contraceptives among childbearing women: findings from a mixed method study in two south western Nigerian States. BMC Public Health, 2018:18, 604; 1-9

[16] Wiebe E. Contraceptive practices and attitudes among immigrant and non-immigrant women in Canada. Canadian Family Physician. 2013; 59: e451-455.

[17] Ojule JD, Abam DS. Contraceptive Trends and Preferred Methods among Users in Port Harcourt, Niger Delta Region of Nigeria. Journal of Biosciences and Medicines. 2017; 5: 97-107.

[18] Nonye-Enyidah EI, Enyidah NS, Eshemogie C. Pattern of contraceptive use at a family planning clinic in southern Nigeria. International Journal of Research in Medical Sciences. 2020; 8(6): 2082-2087.

[19] Muhammad Z, Maimuna DG. Contraceptive trend in a tertiary facility in North Western Nigeria: A 10-year review. Niger J Basic Clin Sci. 2014; 11: 99-103.

[20] Adebara IO, Ijaiya MA. Trends in patterns of contraceptive use in a Nigerian tertiary hospital. J clin med R. 2010; 2(11): 180-184.

[21] Dimkpa OJ, Okwudili OE. Experience with combined injectable contraceptive (Norigynon) in Port Harcourt. British Journal of Medicine \& Medical Research. 2017; 19(1): 01-06.

[22] Abasiattai AM, Bassey EA, Umoiyoho AJ. Contraceptive practice in a tertiary hospital in South-South, Nigeria. Sahel Medical Journal. 2009; 12 (2): 68-72.

[23] Adekunle AO. Recent advances in contraceptive development. In: Okonofua FE, Odunsi K (Eds). Contemporary Obstetrics and Gynaecology for developing countries. Women's Health and Action Research Centre. 2003; 514529. 
[24] Chigbu B, Onwere S, Aluka C, Okoro O. Feyi-Waboso P: Contraceptive choices of women in rural Southeastern Nigeria. Niger J ClinPract. 2010; 13(2): 195-9.

[25] Jejeebhoy SJ. Santhya KG, Zavier AJE. Demand for contraception to delay first pregnancy among young married women in India, Studies in Family Planning. 2014; 45(2): 183-201.

[26] Ikiaki CU, Inaku JE, Ekabua JE, Odusola PO, Njoku CO. Use of combined oral contraceptive pill among teenage girls in Calabar, Nigeria. Open Access Journal of Contraception. 2012; 3: 31-35.

[27] Sedgh G, Hussain R. Reasons for contraceptive nonuse among women having unmet need for contraception in developing countries. Stud Fam Plan. 2014; 45(2): 151-69.

[28] Hindin MJ, McGough LJ, Adanu RM. Misperceptions, misinformation and myths about modern contraceptive use in Ghana. J Family PlannReprod Health Care. 2014; 40(1): 30-5. 